\title{
Methods in Experimental Work Break Research: A Scoping Review
}

\author{
André Scholz ${ }^{1, * \mathbb{D}}$, Johannes Wendsche ${ }^{2}$, Argang Ghadiri ${ }^{1}$, Usha Singh ${ }^{1}$, Theo Peters ${ }^{1}$ \\ and Stefan Schneider ${ }^{3}$ \\ 1 Department of Management Science, Bonn-Rhein-Sieg University of Applied Sciences, 53757 Sankt Augustin, \\ Germany; argang.ghadiri@h-brs.de (A.G.); usha.singh@h-brs.de (U.S.); theo.peters@h-brs.de (T.P.) \\ 2 Federal Institute for Occupational Safety and Health Dresden, 01099 Dresden, Germany; \\ wendsche.johannes@baua.bund.de \\ 3 Institute of Movement and Neuroscience, German Sport University Cologne, 50933 Cologne, Germany; \\ schneider@dshs-koeln.de \\ * Correspondence: andre.scholz@h-brs.de; Tel.: +49-2241-865-145
}

Received: 12 September 2019; Accepted: 6 October 2019; Published: 11 October 2019

check for updates

\begin{abstract}
The number of studies on work breaks and the importance of this subject is growing rapidly, with research showing that work breaks increase employees' wellbeing and performance and workplace safety. However, comparing the results of work break research is difficult since the study designs and methods are heterogeneous and there is no standard theoretical model for work breaks. Based on a systematic literature search, this scoping review included a total of 93 studies on experimental work break research conducted over the last 30 years. This scoping review provides a first structured evaluation regarding the underlying theoretical framework, the variables investigated, and the measurement methods applied. Studies using a combination of measurement methods from the categories "self-report measures," "performance measures," and "physiological measures" are most common and to be preferred in work break research. This overview supplies important information for ergonomics researchers allowing them to design work break studies with a more structured and stronger theory-based approach. A standard theoretical model for work breaks is needed in order to further increase the comparability of studies in the field of experimental work break research in the future.
\end{abstract}

Keywords: experimental design; work break; performance measure; physiological measure; self-report measure; rest break; pause

\section{Introduction}

From a social and economic perspective, companies are becoming increasingly aware of their responsibility for employees' health. As a consequence, the corporate field has shown a rising interest in concepts of "corporate health management" and in a variety of offers related to health benefits for employees [1]. In the organizational setting, work breaks are considered to positively affect employees' physical and cognitive performance, well-being, and health.

The rationale behind work breaks was initially set in working conditions, prevalent decades ago. In times when work was generally associated with strenuous physical activities, employees became tired after a certain time, resulting in more variable or even declining task performance with time on task. They needed a rest to physically recover, often combining this rest with food intake. Although work break scheduling and regulations at that time were subjective and not backed by biological measurements [2], numerous countries passed at least some minimal standards for daily within-shift work breaks, as were passed for Europe [3]. However, in the meantime, despite a significant 
change in workplaces and their psychophysical demands, work break regulations and behavior have basically remained the same.

Earlier research on work breaks focused on performance and productivity [4] and the relation to physical aspects [5] or on incidents and injuries (e.g., [6]). Over time, especially once computers were introduced into office settings and even more because of the change of computer work from less repetitive to more complex [5], research on work breaks changed and mental/psychological strains became a higher attention in work break research $[5,7,8]$.

Investigations into work break research have been conducted in numerous study settings and with varying focuses. Research questioned or focused on either duration, timing, frequency or activity, or a combination of these aspects. Furthermore, there was diversity among the scientific disciplines interacting on work break research (e.g., ergonomics, psychology, work science, medicine) and the investigated variables (e.g., performance, productivity, stress, fatigue, mood, numerous physiological variables). This variety meant that study designs and measurement methods used in work break research were heterogeneous. As a result, there is currently a large number of measurement methods and variables for investigating physiological, psychological, and performance parameters and, unfortunately, with little standardization $[9,10]$. This is the natural consequence of variation in job design factors across work contexts, with the corresponding need to vary associated measures accordingly in relation to specific design factors.

Comparing work break studies is also difficult because the term "work break" has not been uniformly defined and there are so many different types. Work breaks are described with terms such as rest break, rest, lunch break, coffee break, pauses or break meaning the same or, sometimes, specific types of a work interruption. Wendsche and Lohmann-Haislah [11] differentiated between mandatory, optional, or supplementary work breaks and their length and reasons and between regulations in different countries. Mandatory work breaks can be binding for companies because of legislation or for employees because of company regulations. Work breaks can be planned by the company or the employees themselves. Furthermore, they can be triggered by operational procedures such as waiting time or production stops. Work breaks and work break behavior are often strongly linked to regulations in the different countries or even within industries, which can cause difficulties when work break behavior is under employee control [12], potentially leading to conflicts with the legislative regulations. Work breaks can also be distinguished by their length, lasting from a few seconds (micro break) to a few hours (siesta), by their content (e.g., coffee break, toilet break, lunch break), or by their intensity divided into active (e.g., stretching, walking, yoga) and passive (e.g., napping, relaxation) breaks. In our understanding, the term "work break" can be used as a general term to describe any intended interruption of work, regardless of length (e.g., micro break) or content (e.g., lunch break).

The effect of work breaks is multidimensional as they have an influence on physiological and psychological fatigue and strain, on mood, productivity, and social aspects, to name but a few. For example, if employees tire, they are generally less productive; a negative performance effect they can compensate for by working harder, which will lead to greater physiological or psychological strain. To capture these multidimensional effects, it makes sense to include methods from different measurement aspects. O'Donnell and Eggemeier [13] named five criteria for method selection that can also be transferred to work break research: sensitivity, diagnosticity, intrusiveness, implementation requirements, and acceptance by the operator. In particular, the aspects of sensitivity and diagnosticity are decisive aspects in the choice of suitable measurement methods. De Waard [14] also developed O'Donnell and Eggemeier's [13] workload assessment methodology to a three-fold division of variables: self-report measures, performance measures, and physiological measures. The division into three categories is well suited for structuring effects in work break research.

Comparing work break studies is difficult as there is no theoretical model specialized on work breaks. As long as there is no independent theoretical model on the effect of work breaks, it makes sense to use as a basis the general models that take into account aspects of work breaks. Theoretical models 
that have already been used in the context of work breaks are the effort-recovery model by Meijman and Mulder (1998) (e.g., [15,16]) and the conservation of resources theory by Hobfoll (1989) (e.g., [17-19]).

The effort-recovery model [20] describes the positive development of recovery over a period of time when work-related demands no longer continue. Work breaks have an influence on the recovery of load reactions. Work break research can follow this theory by investigating forms of improving the recovery process. The conservation of resources theory [21] describes the stress-related loss of resources and predicts stress outcomes, e.g., in organizational settings. Researchers use this theory as a basis since work breaks influence stress processes and resource gain.

The aims of this review are: (1) To structure previously published intervention studies in work break research and (2) to evaluate them regarding their theoretical and methodical constructs. This review therefore provides a first structured overview of intervention studies on work breaks, their underlying theoretical models, and their measurement methods. This overview is important for ergonomics researchers when designing future work break studies and for extending theory-based knowledge of work breaks. It can help to maximize the positive potential of work breaks. Moreover, our review also intends to uncover possible methodological causes that may have led to inconsistent findings in earlier work break research [8-11].

\section{Materials and Methods}

To describe and summarize the variety of applied measurement methods in work break research, we conducted a scoping review based on the five stages described by Arksey and O'Malley [22]: (1) Identifying the research question, (2) identifying relevant studies, (3) study selection, (4) charting the data, and (5) collating, summarizing, and reporting the results.

\subsection{Stage 1: Identifying the Research Question}

The scoping review was led by the following research questions: (a) Which measurement methods are used in work break research to investigate certain variables? (b) Are there any typical theoretical frameworks or hypotheses for work break research? and (c) Is it possible to standardize the future work break research?

Although we are aware of the problem of defining the term "work break," we wanted to give an overview of applied measurement methods and so did not restrict the identified studies by the varying definitions of "work breaks," accepting a wide definition. We did select the studies for further evaluation according to their intention to investigate work breaks in occupational settings or to give advice on occupational work design.

\subsection{Stage 2: Identifying Relevant Studies}

We started with a systematic review. To identify published studies on work breaks, electronic literature databases that are relevant for potential research in ergonomics, psychology, work science and management, and medicine were searched (PubMed, Web of Science, ScienceDirect), using a publication date from 1989 onward (last 30 years). The period of 30 years was chosen since at that time computers changed workplaces and working structures significantly. The three databases were searched in October 2017, and the search was updated in June 2019. Publications in languages other than English, review articles, book chapters, and conference proceedings were excluded from the methods' evaluation.

Some work break studies have collected their data exclusively through questionnaires, diaries, or surveys. Those studies (e.g., $[19,23,24])$, which come close to a field study in the true sense, have a high value in understanding work breaks. However, because of the focus of this scoping review, studies without manipulation of either work break regimens or content were not included in the review.

For the literature search, we created a specific search string with the following main terms: ('work break" OR 'break*' OR 'pause ${ }^{* \prime}$ OR 'rest break ${ }^{* \prime}$ OR 'lunch break*') AND ('work' OR 'job' OR 'occupation*' OR 'employ*'). 
Additionally, a reference list search was conducted, especially for the systematic reviews and literature reviews described above, to ensure the inclusion of all studies (from 1989 onward) that other researchers had identified as relevant.

A hand-search of key ergonomics journals was conducted to find possibly missed articles from the database searches and references list searches. This search is recommended since electronic databases can be incomplete or outdated or because abstract services can vary in scope, indexing, and depth of information [22].

The selection procedure and the outcomes are shown in Figure 1.

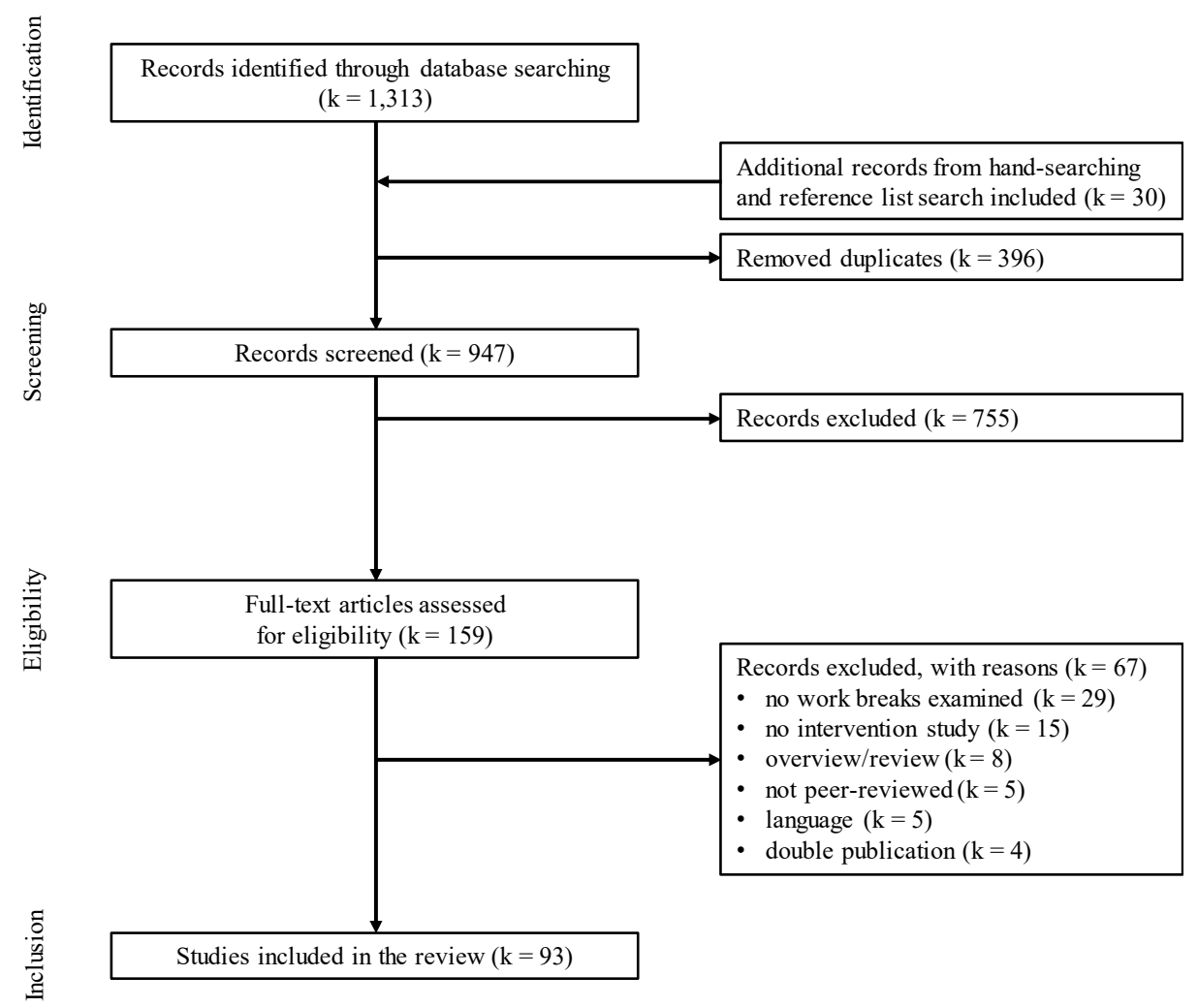

Figure 1. Flow chart on study selection.

\subsection{Stage 3: Study Selection}

The search strategy identified numerous studies that do not focus on work breaks. Since the line of this scoping review was to identify as many measurement methods as possible, particularly strict exclusion criteria for different study designs were not necessary. Nevertheless, a few criteria had to be defined for a better understanding of the research field and to meet certain quality criteria. To be suitable, a study had to (1) investigate intra-shift work breaks, work break regimens, or work break activities, (2) be an intervention study (manipulating at least one aspect of (1)), (3) be peer-reviewed, (4) be in the English language, and (5) be published in full-text. Further quality criteria were not used.

The database search resulted in 1313 records. By excluding duplicates $(\mathrm{k}=396)$ and adding further records from the reference list and hand searches $(\mathrm{k}=30)$, a total of 947 records were screened by title and abstract. Of those records, 755 were discarded mostly because of not investigating on work breaks, resulting in 159 undergoing a full-text screening for suitability. The full-text screening resulted in 93 potentially eligible studies, which were finally included in the review (see Figure 1 for a flow chart).

\subsection{Stage 4: Charting the Data}

The key information of the selected studies was charted in line with the description by Arksey and O'Malley [22]. Comparable to a narrative review, the charted data were comprehensive and non-rating. 
The data (see Table A1) recorded the main information, such as general information (citation), study key data, investigated variables, and applied measurement methods.

\subsection{Stage 5: Collating, Summarizing, and Reporting the Results}

In the next step, the data were transferred into a structure that could reflect the special features of work break research. For this purpose, a separate search was performed to find a suitable basic structure for the examined variables. The structure was then adapted to work break research (see Structure of Variables in Results). In the next step, the first author developed suitable variable-subcategories by viewing and clustering the variables examined by the studies. Afterward, three tables were created for structuring the variables, the variable-subcategories, and the applied measurement methods. One author performed data extraction. A second author checked this extraction for the listed measurement methods. Articles that did not define the applied methods clearly were excluded.

Unlike a systematic review, a scoping review does not synthesize evidence or summarize findings. Thus, this scoping review did not seek to assess quality of evidence and therefore does not determine the studies' robustness or generalizability [22]; it describes the applied methods.

\section{Results}

Table A1 gives an overview of the characteristics of the studies. The following results of the research into measurement methods in work break analysis consists of methods from 93 publications from five continents: America $(\mathrm{k}=36)$, Europe $(\mathrm{k}=33)$, Asia $(\mathrm{k}=17)$, Australia $(\mathrm{k}=6)$, and Africa $(\mathrm{k}=1) .55 \%$ of the studies were conducted in laboratories and $45 \%$ in the field. The review shows an increasing number of studies over the past 30 years, (1989-1998: $\mathrm{k}=22 ; 1999-2008: \mathrm{k}=23 ; 2009-2019$ : $\mathrm{k}=48)$. The examined activities can be divided into predominantly mental activities $(67 \%)$ and predominantly physical activities (33\%) including hospital activities (nursing, surgery), whereby many physical activities are of course also mentally demanding (e.g., concentration in surgery) or emotionally demanding (e.g., nursing). The studies were not dominated by specific industries or job titles. They investigated workplaces that can mainly be described as desk-based computer workstations where the participants worked during the studies. About $56 \%$ of the studies investigated different break regimens, whereas $44 \%$ of the studies focused on activity during work breaks. Two studies $[25,26]$ investigated both break regimen and break activity; they were assigned to the break regimen for further evaluation as they focused on that topic. Almost half the studies (49\%) were exploratory, without formulating a hypothesis. A total of 13 studies (14\%) used a theoretical model as a study design basis. Of these 13 studies, only one theory (resource theory: $[27,28]$ ) occurred more than once. Furthermore, we found that within three decades the focus of work break research seems to be shifting from the United States to Europe and Asia (Table 1) and that the proportion of hypothesis- and theory-based studies has increased in the past decade (Table 2).

Table 1. Change in countries of origin in the last three decades.

\begin{tabular}{ccccc}
\hline Continent & $\mathbf{k}$ & $\mathbf{1 9 8 9 - 1 9 9 8}$ & $\mathbf{1 9 9 9 - 2 0 0 8}$ & $\mathbf{2 0 0 9 - 2 0 1 9}$ \\
\hline America & 36 & 14 & 9 & 13 \\
Europe & 33 & 7 & 8 & 18 \\
Asia & 17 & 1 & 4 & 12 \\
Australia & 6 & 0 & 2 & 4 \\
Africa & 1 & 0 & 0 & 1 \\
Total & 93 & 22 & 23 & 48 \\
\hline
\end{tabular}


Table 2. Distribution of selected study contents over the last three decades.

\begin{tabular}{ccccc}
\hline Study Design & $\mathbf{k}$ & $\mathbf{1 9 8 9 - 1 9 9 8}$ & $\mathbf{1 9 9 9 - 2 0 0 8}$ & $\mathbf{2 0 0 9 - 2 0 1 9}$ \\
\hline Lab study & 51 & 17 & 7 & 27 \\
Field study & 42 & 5 & 16 & 21 \\
Mental work task & 62 & 15 & 10 & 37 \\
Physical work task & 31 & 7 & 13 & 11 \\
Hypothesis-based & 46 & 6 & 8 & 32 \\
Theory-based & 13 & 0 & 0 & 13 \\
\hline
\end{tabular}

As described earlier, measurement methods can be divided into three groups: self-report measures (SRM), performance measures (PER), and physiological measures (PHY) [14]. SRM was used most frequently in $88 \%$ of the studies. PER was used in $61 \%$ of the studies, and PHY in $69 \%$. Most of the studies $(82 \%)$ used measurement methods from two or even all the categories. The combination of the applied measurement methods is shown in Figure 2. A combination of methods from all three categories can be found in more than a third of the studies (37\%), followed by the combination of SRM and PER (22\%) and SRM and PHY (20\%). In field studies, the combination SRM and PER dominates $(26 \%)$, and in laboratory studies, the SMR, PER, and PHY combination dominates (49\%). The combination of SMR, PER, and PHY is most frequently used in the study of break regimens $(37 \%)$ as well as for break activities (37\%). Figure 2 gives an overview of the distribution of the method combinations.

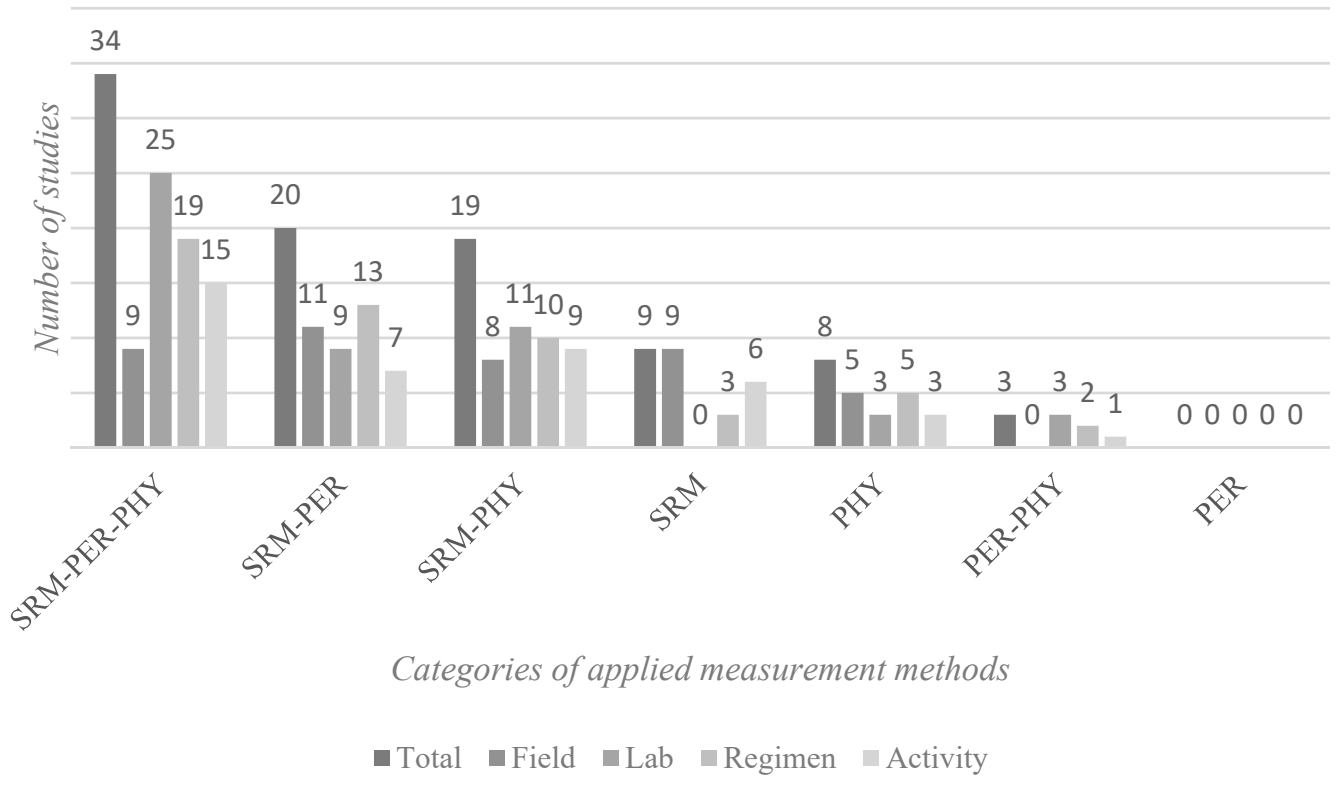

Figure 2. Method combinations in different study settings. Abbreviations: SRM = self-reported measures, $\mathrm{PER}=$ performance measures, $\mathrm{PHY}=$ physiological measures.

De Waard's [14] division into three methodological categories was further classified depending on the study situation. The structure thus provides an overview of the relevance of individual variables and measurement methods. Important for this review is that many of the studies used standardized questionnaires. However, these questionnaires are not always free of overlaps and the variables were investigated using different methods. The studies often only used certain items of a specific questionnaire to examine a variable.

\subsection{Self-Report Measures}

Self-report measures (see Figure 3), often indicated as subjective measures [14], were described by means of standardized or self-designed questionnaires (SDQ) and are the most popular assessment form 
in work break research. Within the self-report measures category, psychological and non-psychological measures can be distinguished. Within the psychological measures, the subdivisions mood/well-being, mental performance, engagement/motivation, workload, and work and break conditions are evident. Within the non-psychological measures, the two subdivisions musculoskeletal discomfort/pain and perceived exertion/fatigue arise.

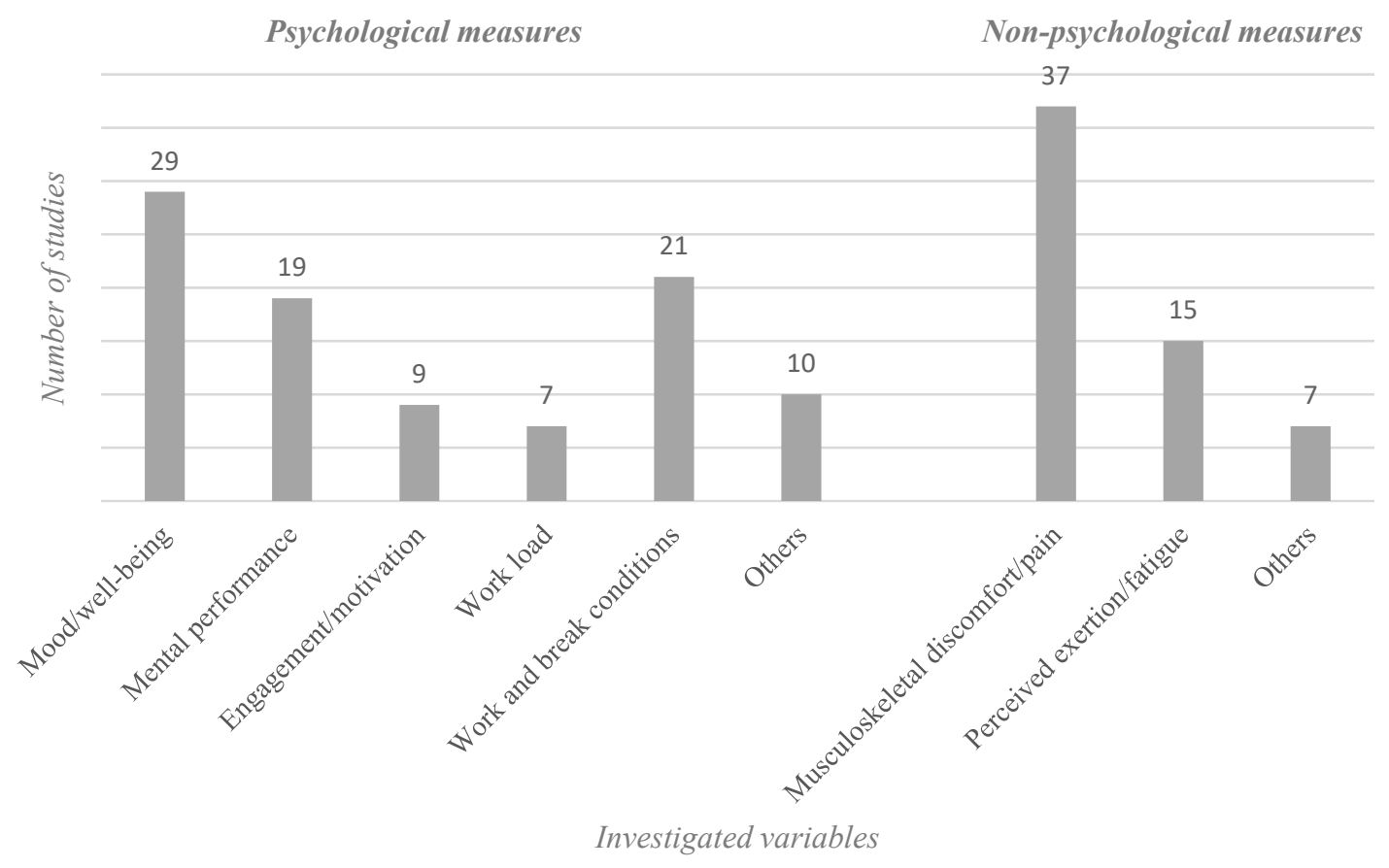

Figure 3. Self-reported measures and the subcategories psychological measures and non-psychological measures. Note: Number of studies investigating on certain variables by using at least one of psychological or non-psychological measures.

\subsubsection{Psychological Measures}

Mood and Well-being. The variable mood/well-being is a central object of investigation in work break research. To measure this state of mind, the Profile of Mood States (POMS; [29]) was most commonly applied. In addition, numerous studies used self-designed questionnaires, often method-based on the Visual Analogue Scale (VAS; first described by Hayes and Paterson [30]), or selecting single scales or items (e.g., rating stress or sleep) from standardized questionnaires.

Mental performance. This variable evaluates cognitive performance in terms of alertness, attention, and concentration. Contrary to this positive state of mind in which personal best possible performance can be achieved, there is sleepiness (usually short term) or fatigue (often a longer lasting state). The Stanford Sleepiness Scale (SSS; [31]) and the Karolinska Sleepiness Scale (KSS; [32]) were the main instruments to examine these mental states.

Engagement and Motivation. The engagement and motivation to accomplish a task are also of interest when considering the effects of a work break and have been investigated using various methods.

Workload. This variable is used to determine a subject's perceived workload. The predominant examination method was the NASA Task Load Index (NASA-TLX; [33]).

Work and break conditions. The category work and break conditions examines aspects of the workplace design and framework conditions and the associated work break design. Motivation for and continuity in practicing the investigated (and mostly newly introduced) work break or work break design also belong to this category. Usually, self-designed questionnaires or diaries were applied here. In evaluating the work breaks, self-designed questionnaires asked for aspects such as personal 
preferences and popularity as well as possible barriers. Since these self-designed questionnaires are usually not published and evaluated, they are not discussed in this review.

Others. In addition to these five categories and the related methods, numerous other self-reported methods (e.g., on quality of life or detachment) have been applied in work break studies. These are diverse and have only rarely been used in work break research. They are therefore not discussed in depth in this review.

\subsubsection{Non-Psychological Measures}

Musculoskeletal discomfort/pain. In the domain of non-psychological assessments, complaints about muscular discomfort or even pain were the most frequently studied variables.

Most of the studies used a Visual Analogue Scale, based on the Borg category ratio scaling (e.g., Borg CR10; [34-36]), to evaluate the general physical condition or, more often, individual body parts. The neck and back were the most frequently examined.

Other tools are a Body Part Diagram/Discomfort Scale developed by Corlett and Bishop [37] and a Visual Analogue Discomfort scale [38].

Perceived exertion/fatigue. Perceived exertion was another variable used to assess the physical effects of work breaks. For this purpose, the Borg Rating of Perceived Exertion Scale (Borg RPE scale; [35,39]) has been applied almost universally. It is used to estimate effort and exertion during physical work, among other variables.

Others. Of the other investigated variables, physical fatigue and physical activity should be highlighted. Physical fatigue was measured differently and was surveyed or determined by physical strength exercises. Physical activity, on the other hand, was usually determined using the International Physical Activity Questionnaire (IPAQ; [40]).

\subsection{Performance Measures}

According to de Waard [14], performance measures can be grouped into primary-task measures, secondary-task measures, and reference tasks. For work break research, that grouping can be reduced to primary tasks and reference tasks (Figure 4).

Primary-task measures

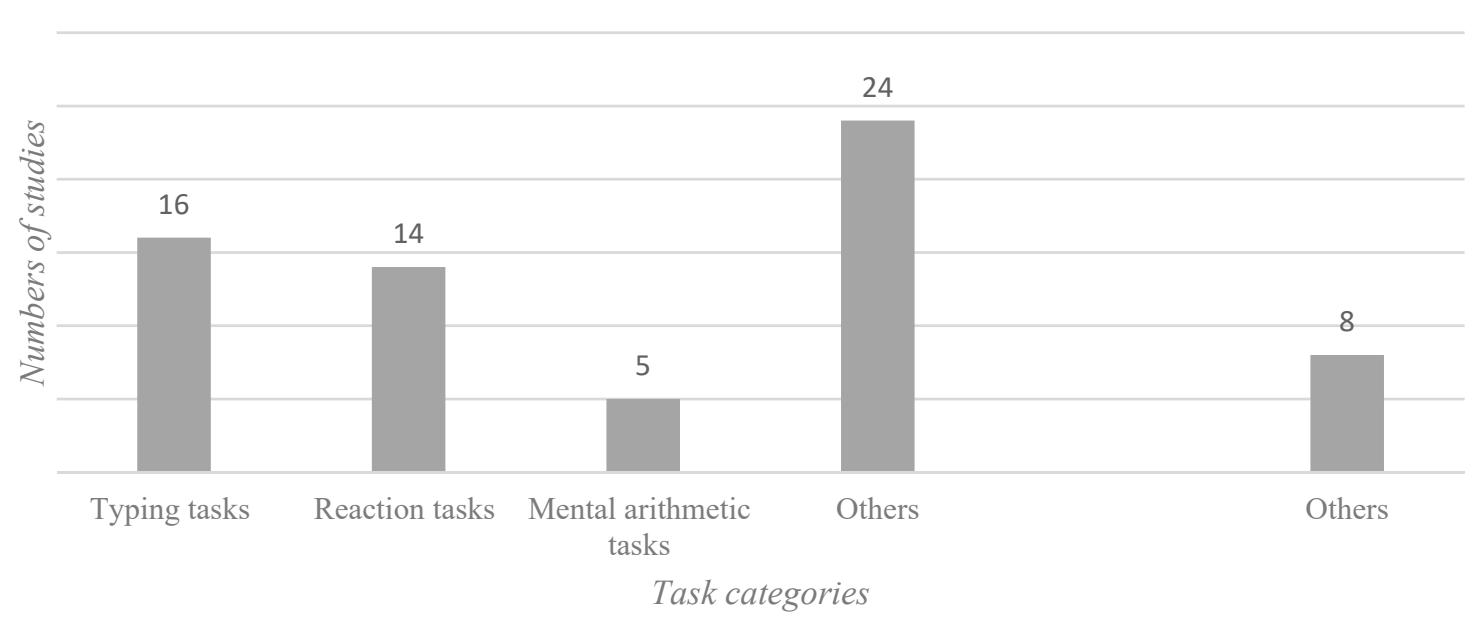

Figure 4. Performance measures and the subcategories primary-task measures and reference tasks. Note: Number of studies investigating different task categories.

Primary tasks were utilized to measure the overall effectiveness. Reference tasks were performed before and after the work break to investigate performance changes through a specific work break regimen or work break activity. 


\subsubsection{Primary Tasks}

In field studies, primary tasks were task specific because of the specificity of the investigated workplace. During quasi-experimental field studies, primary tasks were implemented in the working process and served as a measurable and comparable performance indicator. In laboratory studies, the primary tasks were structured into a few, common tasks. These tasks were often self-designed but aimed at the same measures, such as motor performance, speed of performance, reaction time, accuracy, and number of errors.

Tasks used to measure performance can be divided into typing tasks (keystrokes, error rate, correction rate, number of words typed), reaction tasks (reaction time, accuracy, choice reaction time, auditory reaction time task), and mental arithmetic tasks (mathematical calculation task).

\subsubsection{Reference Tasks}

Reference tasks mainly serve to check for trend effects and are performed under evaluation before and after the task [14], or for work break research before and after the break. Common tasks were memory tasks, concentration tasks, and reaction tasks. The only standardized tasks that was used more than once as a reference task was the $d 2$ Test of Attention (d2; [41]; d2-R; [42]).

\subsection{Physiological Measures}

Within the wide range of physiological measurement methods, four methods stand out because of their frequency (Figure 5). The categories cardiac functions, brain activity, and muscle activity are therefore described in more detail below. Other less frequently applied physiological measurement methods are mentioned in the Others category.

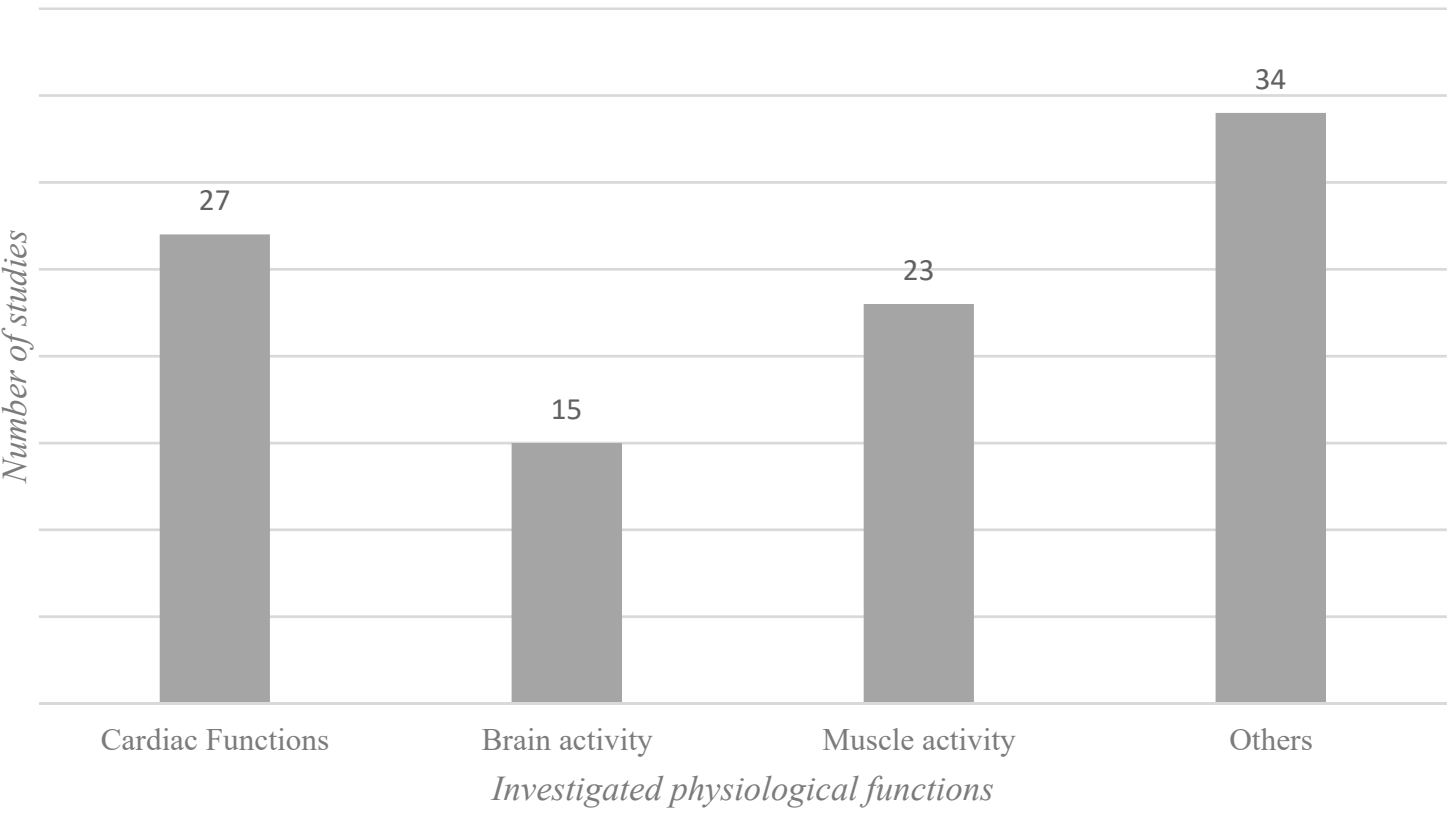

Figure 5. Physiological measures. Note: Number of studies investigating different physiological functions.

\subsubsection{Cardiac Functions}

The cardiac function can be described as the heart's ability to fulfill the metabolic demands of the body. As a result of increased metabolic need, e.g., caused by stress or physical exertion, oxygen demand will increase. To fulfill the oxygen demands, the body can increase the respiratory rate or increase heart rate. The electrocardiogram (ECG) can represent the cardiac function by providing information about the electrical activity conduction through the heart [43]. 
To assess physiological function (and indirect through this, sometimes also mental load, e.g., stress), numerous studies in work break research have measured heart rate and heart rate variability (also described as R-R interval or interbeat interval).

\subsubsection{Brain Activity}

The activity of the brain is conventionally measured using the encephalogram (EEG), which displays oscillations in several, functionally relevant frequency bands [44]. EEG measurements are conducted using one of two methods: Spontaneous EEG, when the neural oscillations of the brain waves are considered, and the event-related potentials (ERP), when the reaction of the EEG after an evoked stimulus is studied. ERPs are often used to determine the reaction time. Functional magnetic resonance imaging (fMRI) is another tool to measure brain activity applied in work break research. In contrast to the EEG, the fMRI shows regional, time-varying changes in the brain activity but is more complex to use because of the clinical scanner involved.

\subsubsection{Muscle Activity}

Another physiological measurement of interest is the activity or inactivity of certain muscles. Muscle activity is investigated in particular in connection with physical labor, monotonous or one-sided movements, or sedentary work behavior, with the main focus on neck and shoulder. In particular, the trapezius muscle is used as a standard to measure the shoulder-neck load in occupational or ergonomics studies [45]. The dominant measurement tool is electromyography (EMG) or, more precisely, surface electromyography (sEMG). In work break research, this non-invasive method is usually used.

\subsubsection{Others}

Further methods in work break research to determine physical functions or the changes of physical parameters because of a certain break regimen or work break activity are eye functions (through electrooculography), spinal shrinkage (through a stadiometer), rest/activity (through actigraphy), sleep, electrodermal activity, temperature, and hormone levels.

\section{Discussion}

This scoping review examined the work break research conducted over the past 30 years (1989 to 2019). We reviewed (1) the development and domains of research in this area, (2) the theoretical rationale behind this research, and (3) the methodological framework used. Using data from 93 studies, this review therefore goes beyond the existing work and is the first review to focus on the theoretical and methodological approaches.

First, an increasing interest in the effect of work breaks and thus an increasing number of studies on work breaks can be clearly observed for the period investigated. In 2009, Trougakos and Hideg [46] identified ergonomics literature as the primary domain investigating within-day work breaks. In 2019, ergonomics literature is still the main publication channel for work break research but its dominance has changed, and research in the area has now been extended to "medicine," "neurology," "physiology," and others. The reviewed studies come from various countries, with the industrial nations clearly dominating the research activities. The work areas examined in the studies are dominated by computer workstations. However, there are also some studies that investigate activities defined by mainly physical activity.

Second, the difficulty in comparing work break studies and their results could be explained by the heterogeneous approach taken in designing and realizing empirical studies. Nearly half of the studies were exploratory and only $14 \%$ of the studies were based on a theoretical model (e.g., resource theory). This is problematic as interpretation of study findings is limited, especially in this case of research where results have been often reported inconsistent across studies. Moreover, it seems that this lack of theory-driven approaches has developed into repeated investigations of rather simple research questions (e.g., Do work breaks reduce mental and physical strain? Which break activities reduce 
mental and physical strain?). In turn, current knowledge on mechanisms and moderators shaping effects of work breaks is sparse. Therefore, future work break research should be more theoretically guided to explain if, when, and why work breaks have any effects on certain outcomes.

Third, with regard to the issues discussed above, the measurement methods used varied greatly across the studies. The measurement methods were sorted according to three categories of measurement variables: "self-report measures," "performance measures," and "physiological measures." The choice of variables to be investigated depended on the study design and the research question. Ideally, a study design considers variables from two or even all three categories [14].

To examine the multidimensional effects of a work break, using a number of measurement methods is reasonable and a large number of methods for measuring each individual variable are already available, especially in the case of self-reported measures. In most papers, the authors explained their method choice simply by referring to the method being used in previous work. Few studies provide an independent evaluation of the method, especially with regard to the sensitivity and diagnosticity, which are related to the individual study design. The methodological heterogeneity of the research limits a final evaluation of previous results in all relevant aspects of work break research such as performance, motivation, well-being, health, break regimen, break location, and break content [11].

A combination of measurement methods of self-report measures, performance measures, and physiological measures is a promising approach to determine interdependencies of the multidimensional effects $[11,14]$ and has been repeatedly recommended for future research (e.g., $[18,23])$. The combination of measurement methods from the three measure categories will lead to better results. These methods should be evaluated regarding the five criteria by O'Donnell and Eggemeier [13] especially sensitivity and diagnosticity. Furthermore, the scientific community recommends describing the methods' objectivity, validity, and reliability. A description of objectivity, validity, and reliability (e.g., $[47,48]$ ) was given on $11 \%$ of the reviewed studies. Especially in studies with a small number of test persons, effect sizes should be reported (e.g., [49,50]).

The sample selection and sample planning are other critical points. As in many other areas of research, rest break research often uses students as participants in lab studies. In studies that investigate aspects such as stress experience, physical discomfort, and compensatory capacity, this group of young and, in general, healthier people is not necessarily transferable to the work situation and the average employee. Sample planning can only be found sporadically in the studies investigated (e.g., [51]), but could help to improve results in terms of practical relevance in the future.

A central role in evaluating measurement results in work break research is certainly played by the individual level of demands. The individual course of demands and the individual course of recovery from these demands still offer investigative potential and would allow work break effects to be evaluated from the process perspective. In particular, for a detailed assessment of the performance and recovery processes, a distinction must be made between an investigation of the demands and recovery at one point in time or over a certain period of time.

We would like to note that the results of our review are limited by scope of literature search (e.g., selection of electronic databases, search string, inclusion and exclusion criteria). However, we think that the potential of a publication bias is low here as we used databased literature search, inspection of references, and hand-search of journals in combination which resulted in a much higher number of included studies than in other current reviews on work breaks [8-11].

\section{Conclusions}

Work breaks are an important measure to offer employees time to immediately recover from work-related consequences of strain after high work demands and, in turn, to improve their mental and physical wellbeing, their performance, and workplace safety.

In our review we set out to structure and evaluate the experimental work break research from 1989 to 2019 ( $k=93$ studies), since there are manifold ways of analyzing the effects of work breaks regarding study designs and measurement methods. 
Most of the examined studies were exploratory, thus, missing a theoretical foundation. Moreover, during the last 30 years most researchers applied previously used measurement methods without evaluating them for their own studies; neither regarding criteria as sensitivity and diagnosticity nor regarding the methods' objectivity, validity, and reliability.

In sum, in future studies it would be desirable to develop a theoretical model that is focused on the particular and various effects of work breaks and can serve as a standard model for future work break studies [52]. Furthermore, variables measured by methods out of all three categories ("self-report measures," "performance measures," and "physiological measures") should be considered in future study designs.

Author Contributions: Conceptualization, A.S., J.W., A.G. and S.S.; investigation, A.S.; formal analysis, A.S., A.G. and U.S.; visualization, A.S.; writing — original draft preparation, A.S. and U.S.; writing—review and editing, J.W., A.S., U.S., T.P. and S.S.

Funding: This research received no external funding.

Acknowledgments: We thank Anne Wegner for proofreading and Nils Günzel for his technical support. André Scholz was supported by a research grant from the Graduate Institute of Bonn-Rhein-Sieg University of Applied Sciences. We would like to thank two unknown reviewer for their valuable comments on a previous version of this manuscript.

Conflicts of Interest: The authors declare no conflict of interest. 


\section{Appendix A}

Table A1. Characteristics and categories of applied measurement methods of included studies. Abbreviations: SRM = self-reported measures, PER $=$ performance measures, PHY = physiological measures.

\begin{tabular}{|c|c|c|c|c|c|c|c|c|c|c|c|c|c|}
\hline \multirow[b]{2}{*}{ Author } & \multirow[b]{2}{*}{ Year } & \multirow[b]{2}{*}{ Country } & \multirow[b]{2}{*}{ Site } & \multirow[b]{2}{*}{ Work/Task } & \multirow[b]{2}{*}{ Sample Size } & \multirow[b]{2}{*}{ Days } & \multirow[b]{2}{*}{ Time-on-Task } & \multirow[b]{2}{*}{ Object } & \multirow[b]{2}{*}{ Hypothesis } & \multirow[b]{2}{*}{ Theory/Model } & \multicolumn{3}{|c|}{ Applied Measurement Methods } \\
\hline & & & & & & & & & & & SRM & PER & PHY \\
\hline Arrabito et al. [53] & 2011 & Canada & $\mathrm{Lab}$ & Mental & 98 & 1 & $40 \mathrm{~min}$ & Activity & no & no & yes & yes & \\
\hline Arrabito et al. [54] & 2015 & Canada & $\mathrm{Lab}$ & Mental & 150 & 1 & $40 \mathrm{~min}$ & Activity & yes & yes & yes & yes & \\
\hline Balci and Aghazadeh [55-57] & $\begin{array}{l}2000 \\
(2003, \\
2004)\end{array}$ & USA & $\mathrm{Lab}$ & Mental & 10 & 1 & $120 \mathrm{~min}$ & Regimen & no & no & yes & yes & yes \\
\hline Beynon and Reilly [58] & 2001 & UK & $\mathrm{Lab}$ & Physical & 10 & 2 & $240 \mathrm{~min}$ & Activity & yes & no & yes & & yes \\
\hline Beynon et al. [59] & 2000 & UK & $\mathrm{Lab}$ & Physical & 8 & 2 & $\begin{array}{l}\text { full working } \\
\text { day }\end{array}$ & Regimen & yes & no & yes & & yes \\
\hline Boucsein and Thum $[5,60]$ & $\begin{array}{l}1995 \\
(1997) \\
\end{array}$ & Germany & Field & Mental & 11 & 2 & $\begin{array}{l}\text { full working } \\
\text { day }\end{array}$ & Regimen & no & no & yes & & yes \\
\hline Brown et al. [51] & 2014 & UK & Field & Mental & 73 & 56 & $\begin{array}{l}\text { full working } \\
\text { day }\end{array}$ & Activity & yes & no & yes & & yes \\
\hline Byström et al. [61] & 1991 & Sweden & $\mathrm{Lab}$ & Physical & 8 & 1 & $3 \mathrm{~min}$ & Activity & no & no & yes & yes & yes \\
\hline Chaikumarn et al. [62] & 2018 & Thailand & $\mathrm{Lab}$ & Mental & 30 & 1 & $60 \mathrm{~min}$ & Activity & yes & no & & yes & yes \\
\hline Chakrabarty et al. [63] & 2016 & India & Field & Physical & 400 & 120 & $360 \mathrm{~min}$ & Regimen & yes & no & yes & & \\
\hline Chavaillaz et al. [64] & 2019 & Switzerland & Lab & Mental & 72 & 1 & $60 \mathrm{~min}$ & Regimen & yes & yes & yes & yes & \\
\hline Christensen et al. [65] & 2000 & Denmark & Field & Physical & 48 & 1 & $\begin{array}{l}\text { full working } \\
\text { day }\end{array}$ & Regimen & yes & no & & & yes \\
\hline Coburn et al. [66] & 2006 & Germany & Field & Physical & 30 & 2 & $450 \mathrm{~min}$ & Regimen & yes & no & yes & yes & \\
\hline Constable et al. [67] & 1994 & USA & $\mathrm{Lab}$ & Physical & 8 & 1 & $180 \mathrm{~min}$ & Activity & yes & no & & & yes \\
\hline Cordoza et al. [68] & 2018 & USA & Field & Physical & 29 & 84 & $\begin{array}{l}\text { full working } \\
\text { day }\end{array}$ & Activity & no & no & yes & & \\
\hline Crenshaw et al. [69] & 2006 & Sweden & $\mathrm{Lab}$ & Mental & 15 & 2 & $60 \mathrm{~min}$ & Activity & yes & no & yes & yes & yes \\
\hline Dababneh et al. [70] & 2001 & USA & Field & Physical & 30 & 36 & $\begin{array}{l}\text { full working } \\
\text { day }\end{array}$ & Regimen & no & no & yes & yes & \\
\hline Davis and Kotowski [71] & 2014 & USA & Field & Mental & 37 & 40 & $\begin{array}{l}\text { full working } \\
\text { day }\end{array}$ & Regimen & no & no & yes & yes & yes \\
\hline Davy and Göbel [25] & 2013 & Germany & $\mathrm{Lab}$ & Physical & 24 & 3 & full night shift & Regimen & no & no & yes & yes & yes \\
\hline de Looze et al. [72] & 2010 & $\begin{array}{l}\text { The } \\
\text { Netherlands }\end{array}$ & Field & Physical & 14 & 3 & $440 \mathrm{~min}$ & Regimen & no & no & yes & yes & \\
\hline
\end{tabular}


Table A1. Cont.

\begin{tabular}{|c|c|c|c|c|c|c|c|c|c|c|c|c|c|}
\hline \multirow[b]{2}{*}{ Author } & \multirow[b]{2}{*}{ Year } & \multirow[b]{2}{*}{ Country } & \multirow[b]{2}{*}{ Site } & \multirow[b]{2}{*}{ Work/Task } & \multirow[b]{2}{*}{ Sample Size } & \multirow[b]{2}{*}{ Days } & \multirow[b]{2}{*}{ Time-on-Task } & \multirow[b]{2}{*}{ Object } & \multirow[b]{2}{*}{ Hypothesis } & \multirow[b]{2}{*}{ Theory/Model } & \multicolumn{3}{|c|}{ Applied Measurement Methods } \\
\hline & & & & & & & & & & & SRM & PER & PHY \\
\hline Dorion and Darveau [73] & 2013 & Canada & Field & Physical & 16 & 3 & $\begin{array}{l}\text { full working } \\
\text { day }\end{array}$ & Regimen & yes & no & yes & yes & yes \\
\hline Engelmann et al. [74] & 2011 & Germany & Field & Physical & 7 & 1 & $\begin{array}{c}\text { full working } \\
\text { day }\end{array}$ & Regimen & yes & no & yes & yes & yes \\
\hline Faucett et al. [75] & 2007 & USA & Field & Physical & $66 / 32$ & $2 / 6$ & $480 \mathrm{~min}$ & Regimen & no & no & yes & yes & \\
\hline Frey et al. [76] & 2002 & Austria & Field & Physical & 11 & 2 & full 24h shift & Activity & no & no & yes & yes & yes \\
\hline Galinsky et al. [77] & 2000 & USA & Field & Physical & 42 & 60 & $\begin{array}{c}\text { full working } \\
\text { day }\end{array}$ & Regimen & no & no & yes & yes & \\
\hline Galinsky et al. [78] & 2007 & USA & Field & Mental & 51 & 56 & $\begin{array}{l}\text { full working } \\
\text { day }\end{array}$ & Regimen & no & no & yes & yes & \\
\hline Garcia et al. [79] & 2018 & Switzerland & $\mathrm{Lab}$ & Physical & 30 & 2 & $300 \min$ & Regimen & yes & no & yes & & yes \\
\hline Genaidy and al-Rayes [80] & 1993 & USA & $\mathrm{Lab}$ & Physical & $5 / 8$ & 2 & $240 \mathrm{~min}$ & Regimen & no & no & yes & yes & yes \\
\hline Genaidy et al. [81] & 1995 & USA & Field & Physical & 28 & 28 & $\begin{array}{l}\text { full working } \\
\text { day }\end{array}$ & Regimen & no & no & yes & & \\
\hline Hayashi et al. [82] & 2004 & Japan & Field & Mental & 10 & 2 & $120 \mathrm{~min}$ & Activity & no & no & yes & yes & yes \\
\hline Helander and Quance [83] & 1990 & USA & $\mathrm{Lab}$ & Mental & 7 & 4 & $200 \mathrm{~min}$ & Regimen & yes & no & & & yes \\
\hline Henning et al. [84] & 1989 & USA & $\mathrm{Lab}$ & Mental & 20 & 2 & $120 \mathrm{~min}$ & Regimen & yes & no & yes & yes & yes \\
\hline Henning et al. [86] & 1994a & USA & Lab & Mental & 31 & 1 & $65 \mathrm{~min}$ & Regimen & no & no & yes & yes & yes \\
\hline Henning et al. [87] & $1994 \mathrm{~b}$ & USA & Lab & Mental & 38 & 1 & $48 \mathrm{~min}$ & Regimen & no & no & yes & yes & yes \\
\hline Henning et al. [88] & 1995 & USA & Lab & Mental & 30 & 1 & $55 \mathrm{~min}$ & Regimen & no & no & yes & yes & yes \\
\hline Henning et al. [89] & 1996 & USA & Lab & Mental & $31 / 30$ & 1 & $60 \mathrm{~min}$ & Regimen & no & no & yes & yes & yes \\
\hline Henning et al. [26] & 1997a & USA & Field & Mental & $73 / 19$ & $28 / 42$ & $\begin{array}{c}\text { full working } \\
\text { day }\end{array}$ & Regimen & yes & no & yes & yes & \\
\hline Henning et al. [90] & $1997 \mathrm{~b}$ & USA & $\mathrm{Lab}$ & Mental & 60 & 1 & $46 \mathrm{~min}$ & Regimen & no & no & yes & yes & yes \\
\hline Hirose and Nagasaka [91] & 2003 & Japan & $\mathrm{Lab}$ & Mental & 8 & 1 & $100 \min$ & Activity & no & no & yes & yes & yes \\
\hline Hofer-Tinguely et al. [92] & 2005 & Switzerland & Lab & Physical & 50 & 1 & $60 \mathrm{~min}$ & Activity & no & no & yes & yes & yes \\
\hline Howard et al. [93] & 2010 & Australia & $\mathrm{Lab}$ & Mental & 8 & 3 & full night shift & Regimen & no & no & yes & yes & yes \\
\hline Irmak et al. [94] & 2012 & Turkey & Field & Mental & 39 & 70 & $\begin{array}{c}\text { full working } \\
\text { day }\end{array}$ & Regimen & no & no & yes & & \\
\hline Januario et al. [95] & 2018 & Brazil & $\mathrm{Lab}$ & Physical & 18 & 1 & $40 \mathrm{~min}$ & Activity & yes & no & yes & & yes \\
\hline Kakarot et al. [96] & 2012 & Germany & Lab & Physical & 29 & 2 & $420 \mathrm{~min}$ & Regimen & yes & no & yes & & yes \\
\hline Karwowski et al. [97] & 1994 & USA & $\mathrm{Lab}$ & Mental & 12 & 12 & $240 \mathrm{~min}$ & Regimen & yes & no & yes & & yes \\
\hline
\end{tabular}


Table A1. Cont.

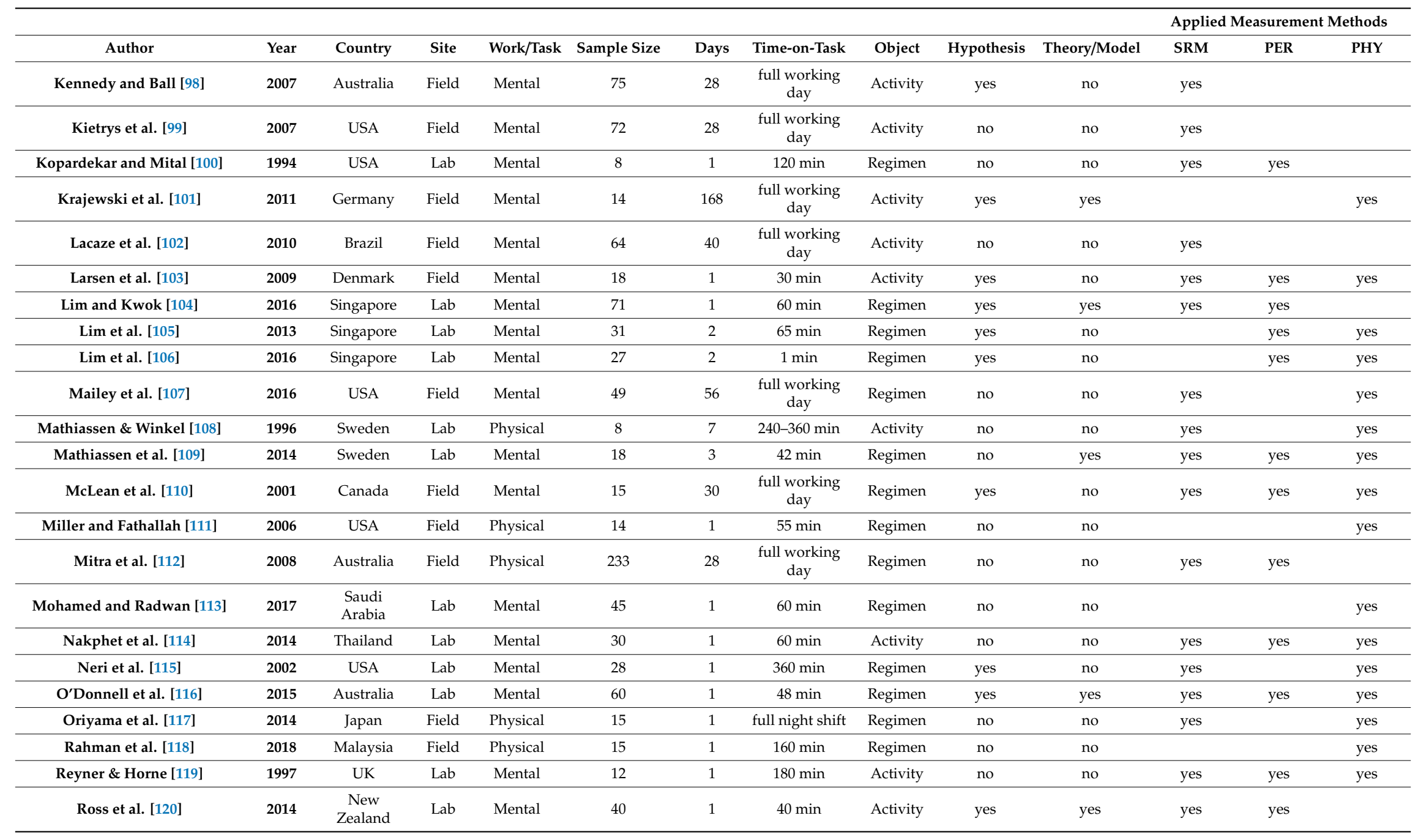


Table A1. Cont.

\begin{tabular}{|c|c|c|c|c|c|c|c|c|c|c|c|c|c|}
\hline \multirow[b]{2}{*}{ Author } & \multirow[b]{2}{*}{ Year } & \multirow[b]{2}{*}{ Country } & \multirow[b]{2}{*}{ Site } & \multirow[b]{2}{*}{ Work/Task } & \multirow[b]{2}{*}{ Sample Size } & \multirow[b]{2}{*}{ Days } & \multirow[b]{2}{*}{ Time-on-Task } & \multirow[b]{2}{*}{ Object } & \multirow[b]{2}{*}{ Hypothesis } & \multirow[b]{2}{*}{ Theory/Model } & \multicolumn{3}{|c|}{ Applied Measurement Method } \\
\hline & & & & & & & & & & & SRM & PER & PHY \\
\hline Rupp et al. [121] & 2017 & USA & $\mathrm{Lab}$ & Mental & 65 & 1 & $15 \mathrm{~min}$ & Activity & yes & yes & yes & yes & \\
\hline Samani et al. [122] & $2009 a$ & Denmark & $\mathrm{Lab}$ & Mental & 12 & 2 & $12+4 \min$ & Activity & yes & yes & yes & & yes \\
\hline Samani et al. [123] & $2009 \mathrm{~b}$ & Denmark & $\mathrm{Lab}$ & Mental & 12 & 1 & $40 \mathrm{~min}$ & Activity & yes & no & yes & & yes \\
\hline Schnieder et al. [124] & 2013 & Germany & Field & Mental & 14 & 180 & $\begin{array}{l}\text { full working } \\
\text { day }\end{array}$ & Activity & yes & no & yes & yes & \\
\hline Scholz et al. [50] & 2018 & Germany & $\mathrm{Lab}$ & Mental & 12 & 4 & $120 \mathrm{~min}$ & Activity & yes & no & yes & yes & yes \\
\hline Sheahan et al. [125] & 2016 & Canada & $\mathrm{Lab}$ & Mental & 20 & 4 & $60-70 \mathrm{~min}$ & Regimen & yes & no & yes & yes & yes \\
\hline Sianoja et al. [15] & 2017 & Finland & Field & Mental & 97 & 10 & $\begin{array}{l}\text { full working } \\
\text { day }\end{array}$ & Activity & yes & yes & yes & & \\
\hline Sommer et al. [126] & 2013 & Germany & $\mathrm{Lab}$ & Mental & 32 & 2 & 0 & Activity & yes & no & yes & yes & yes \\
\hline Steinborn and Hystegge [127] & 2016 & Germany & $\mathrm{Lab}$ & Mental & 68 & 1 & $50 \mathrm{~min}$ & Activity & yes & yes & yes & yes & \\
\hline St-Onge et al. [128] & 2017 & Canada & $\mathrm{Lab}$ & Mental & 27 & 1 & $40 \mathrm{~min}$ & Activity & yes & no & yes & yes & yes \\
\hline Sun et al. [49] & 2017 & Singapore & $\mathrm{Lab}$ & Mental & 20 & 2 & $22 \mathrm{~min}$ & Regimen & yes & yes & yes & yes & yes \\
\hline Sundelin [129] & 1993 & Sweden & $\mathrm{Lab}$ & Physical & 12 & 1 & $120 \mathrm{~min}$ & Activity & no & no & yes & & yes \\
\hline Sundelin and Hagberg [130] & 1989 & Sweden & Field & Mental & 12 & 1 & $90 \mathrm{~min}$ & Activity & no & no & yes & & yes \\
\hline Takahashi et al. [131] & 1998 & Japan & $\mathrm{Lab}$ & Mental & 30 & 1 & $\begin{array}{l}\text { full working } \\
\text { day }\end{array}$ & Regimen & yes & no & yes & yes & yes \\
\hline Takahashi et al. [132] & 2004 & Japan & Field & Physical & 8 & 21 & $\begin{array}{l}\text { full working } \\
\text { day }\end{array}$ & Activity & no & no & yes & yes & yes \\
\hline Taylor et al. [133] & 2013 & USA & Field & Mental & 35 & $180 / 365$ & $\begin{array}{l}\text { full working } \\
\text { day }\end{array}$ & Activity & no & no & yes & & \\
\hline Taylor et al. [47] & 2016 & USA & Field & Mental & 175 & 180 & $\begin{array}{l}\text { full working } \\
\text { day }\end{array}$ & Activity & yes & no & yes & & yes \\
\hline Tiwari and Gite [134] & 2006 & India & Field & Physical & 5 & 4 & $360 \mathrm{~min}$ & Regimen & no & no & yes & & yes \\
\hline Torrente et al. [135] & 2017 & Finland & Field & Mental & 153 & 30 & $\begin{array}{l}\text { full working } \\
\text { day }\end{array}$ & Activity & yes & yes & & & yes \\
\hline van den Heuvel et al. [136] & 2003 & $\begin{array}{l}\text { The } \\
\text { Netherlands }\end{array}$ & Field & Mental & 268 & 60 & $\begin{array}{l}\text { full working } \\
\text { day }\end{array}$ & Activity & no & no & yes & yes & \\
\hline $\begin{array}{c}\text { van Dieen and Oude Vrielink } \\
{[137]}\end{array}$ & 1998 & $\begin{array}{l}\text { The } \\
\text { Netherlands }\end{array}$ & Field & Physical & 12 & 3 & $\begin{array}{l}\text { full working } \\
\text { day }\end{array}$ & Regimen & no & no & yes & & yes \\
\hline Wang and Pei [138] & 2014 & China & Field & Mental & 33 & 1 & $120-240 \mathrm{~min}$ & Regimen & no & no & yes & yes & \\
\hline Watling et al. [48] & 2014 & Australia & $\mathrm{Lab}$ & Mental & 20 & 1 & $180 \mathrm{~min}$ & Activity & yes & no & yes & yes & yes \\
\hline Wollseiffen et al. [139] & 2015 & Germany & Field & Mental & 50 & 1 & $\begin{array}{l}\text { full working } \\
\text { day }\end{array}$ & Activity & yes & no & yes & yes & yes \\
\hline
\end{tabular}




\section{References}

1. Montano, D.; Hoven, H.; Siegrist, J. Effects of organisational-level interventions at work on employees' health: A systematic review. BMC Public Health 2014, 14, 135. [CrossRef] [PubMed]

2. Bhatia, N.; Murrel, K.F.H. An industrial experiment in organized rest pauses. Hum. Factors 1969, 11, $167-174$. [CrossRef] [PubMed]

3. European Parliament. Directive 2003/88/EC of the European Parliament and of the Council of 4 November 2003 Concerning Certain Aspects of the Organisation of Working Time; European Parliament: Brussels, Belgium, 2003; Volume Directive 2003/88/EC.

4. Bechtold, S.E.; Janaro, R.E.; Sumners, D.W.L. Maximization of labor productivity through optimal rest-break schedules. Manag. Sci. 1984, 30, 1442-1458. [CrossRef]

5. Boucsein, W.; Thum, M. Design of work/rest schedules for computer work based on psychophysiological recovery measures. Int. J. Ind. Ergon. 1997, 20, 51-57. [CrossRef]

6. Pragier, E. Work breaks for keyboard operators. Aust. J. Physiother. 1986, 32, 157-160. [CrossRef]

7. Ghadiri, A. Arbeitspausen in der betrieblichen Gesundheitsförderung. ZFO 2016, 85, 270-276.

8. Tucker, P. The impact of rest breaks upon accident risk, fatigue and performance: A review. Work Stress 2003, 17, 123-137. [CrossRef]

9. Barredo, R.D.V.; Mahon, K. The effects of exercise and rest breaks on musculoskeletal discomfort during computer tasks: An evidence-based perspective. J. Phys. Therapy Sci. 2007, 19, 151-163. [CrossRef]

10. Brewer, S.; Eerd, D.V.; Amick, B.C., III; Irvin, E.; Daum, K.M.; Gerr, F.; Moore, J.S.; Cullen, K.; Rempel, D. Workplace interventions to prevent musculoskeletal and visual symptoms and disorders among computer users: A systematic review. J. Occup. Rehab. 2006, 16, 317-350. [CrossRef]

11. Wendsche, J.; Lohmann-Haislah, A. Psychische Gesundheit in der Arbeitswelt: Pausen; Bundesanstalt für Arbeitsschutz und Arbeitsmedizin: Dortmund, Germany; Berlin, Germany; Dresden, Germany, 2016.

12. Zhu, Z.; Kuykendall, L.; Zhang, X. The impact of within-day work breaks on daily recovery processes: An event-based pre-/post-experience sampling study. J. Occup. Organ. Psychol. 2019, 92, 191-211. [CrossRef]

13. O'Donnell, R.D.; Eggemeier, F.T. Workload assessment methodology. In Handbook of Perception and Human Performance Vol. 2: Cognitive Processes and Performance; John Wiley \& Sons: Oxford, UK, 1986; pp. 1-49, ISBN 0-471-82956-0.

14. De Waard, D. The Measurement of Drivers' Mental Workload; University of Groningen: Groningen, The Netherlands, 1996; ISBN 978-90-6807-308-9.

15. Sianoja, M.; Syrek, C.J.; de Bloom, J.; Korpela, K.; Kinnunen, U. Enhancing daily well-being at work through lunchtime park walks and relaxation exercises: Recovery experiences as mediators. J. Occup. Health Psychol. 2017, 23, 428. [CrossRef]

16. Kim, S.; Park, Y.; Niu, Q. Micro-break activities at work to recover from daily work demands. J. Organ. Behav. 2017, 38, 28-44. [CrossRef]

17. Zacher, H.; Brailsford, H.A.; Parker, S.L. Micro-breaks matter: A diary study on the effects of energy management strategies on occupational well-being. J. Vocat. Behav. 2014, 85, 287-297. [CrossRef]

18. Kuehnel, J.; Zacher, H.; de Bloom, J.; Bledow, R. Take a break! Benefits of sleep and short breaks for daily work engagement. Eur. J. Work Organ. Psychol. 2017, 26, 481-491. [CrossRef]

19. Bosch, C.; Sonnentag, S.; Pinck, A.S. What makes for a good break? A diary study on recovery experiences during lunch break. J. Occup. Organ. Psychol. 2018, 91, 134-157. [CrossRef]

20. Meijman, T.F.; Mulder, G. Psychological aspects of workload. In A Handbook of Work and Organizational Psychology; Drenth, P.J.D., Thierry, H., de Wolff, C.J., Eds.; Psychology Press: Hove, UK, 1998; pp. 5-34.

21. Hobfoll, S.E. Conservation of resources: A new attempt at conceptualizing stress. Am. Psychol. 1989, 44, 513-524. [CrossRef]

22. Arksey, H.; O’Malley, L. Scoping studies: Towards a methodological framework. Int. J. Soc. Res. Methodol. 2005, 8, 19-32. [CrossRef]

23. Kim, S.; Park, Y.; Headrick, L. Daily micro-breaks and job performance: General work engagement as a cross-level moderator. J. Appl. Psychol. 2018, 103, 772-786. [CrossRef] 
24. Sianoja, M.; Kinnunen, U.; de Bloom, J.; Korpela, K.; Geurts, S. Recovery during Lunch Breaks: Testing Long-Term Relations with Energy Levels at Work. Scan. J. Work Organ. Psychol. 2016, 1, 7. [CrossRef]

25. Davy, J.; Göbel, M. The effects of a self-selected nap opportunity on the psychophysiological, performance and subjective measures during a simulated industrial night shift regimen. Ergonomics 2013, 56, 220-234. [CrossRef]

26. Henning, R.A.; Jacques, P.; Kissel, G.V.; Sullivan, A.B.; Alteras-Webb, S.M. Frequent short rest breaks from computer work: Effects on productivity and well-being at two field sites. Ergonomics 1997, 40, 78-91. [CrossRef] [PubMed]

27. Kahneman, D. Attention and Effort; Prentice-Hall Series in Experimental Psychology; Prentice-Hall: Englewood Cliffs, NJ, USA, 1973; ISBN 978-0-13-050518-7.

28. Warm, J.S.; Parasuraman, R.; Matthews, G. Vigilance requires hard mental work and is stressful. Hum. Factors J. Hum. Factors Ergon. Soc. 2008, 50, 433-441. [CrossRef] [PubMed]

29. McNair, D.M.; Lorr, M.; Droppleman, L.F. Profile of Mood States; Educational and Industrial Testing Service: San Diego, CA, USA, 1971.

30. Hayes, M.; Patterson, D. Experimental development of the graphic rating method. Psychol. Bull. 1921, 98-99.

31. Hoddes, E.; Zarcone, V.; Smythe, H.; Phillips, R.; Dement, W.C. Quantification of sleepiness: A new approach. Psychophysiology 1973, 10, 431-436. [CrossRef] [PubMed]

32. Akerstedt, T.; Gillberg, M. Subjective and objective sleepiness in the active individual. Int. J. Neurosci. 1990, 52, 29-37. [CrossRef] [PubMed]

33. Hart, S.G.; Staveland, L.E. Development of NASA-TLX (Task Load Index): Results of empirical and theoretical research. Adv. Psychol. 1988, 52, 139-183.

34. Borg, G. Physical Performance and Perceived Exertion; University Lund: Oxford, UK, 1962.

35. Borg, G. Psychophysical bases of perceived exertion. Med. Sci. Sports Exerc. 1982, 14, 377-381. [CrossRef] [PubMed]

36. Borg, G. Anstrengungsempfinden und körperliche Aktivität. Dtsch. Arztebl. Int. 2004, 101, A-1016.

37. Corlett, E.N.; Bishop, R.P. A technique for assessing postural discomfort. Ergonomics 1976, 19, $175-182$. [CrossRef]

38. Huskisson, E.C. Measurement of pain. Lancet 1974, 2, 1127-1131. [CrossRef]

39. Borg, G. Perceived exertion as an indicator of somatic stress. Scand. J. Rehabil. Med. 1970, 2, 92-98. [PubMed]

40. Craig, C.L.; Marshall, A.L.; Sjöström, M.; Bauman, A.E.; Booth, M.L.; Ainsworth, B.E.; Pratt, M.; Ekelund, U.; Yngve, A.; Sallis, J.F.; et al. International physical activity questionnaire: 12-country reliability and validity. Med. Sci. Sports Exerc. 2003, 35, 1381-1395. [CrossRef] [PubMed]

41. Brickenkamp, R.; Zillmer, E. d2 Test of Attention; Hogrefe: Göttingen, Germany, 1998.

42. Brickenkamp, R.; Schmidt-Atzert, L.; Liepmann, D. Test d2-Revision Aufmerksamkeits-und Konzentrationstest; Hogrefe: Göttingen, Germany, 2010.

43. Carreiro, J. The cardiovascular system. In An Osteopathic Approach to Children; Elsevier: Amsterdam, The Netherlands, 2009; pp. 73-83, ISBN 978-0-443-06738-9.

44. Moffett, S.X.; O'Malley, S.M.; Man, S.; Hong, D.; Martin, J.V. Dynamics of high frequency brain activity. Sci. Rep. 2017, 7. [CrossRef] [PubMed]

45. Mathiassen, S.E.; Winkel, J.; Hägg, G.M. Normalization of surface EMG amplitude from the upper trapezius muscle in ergonomic studies-A review. J. Electromyogr. Kinesiol. 1995, 5, 197-226. [CrossRef]

46. Trougakos, J.P.; Hideg, I. Momentary work recovery: The role of within-day work breaks. In Current Perspectives on Job-Stress Recovery; Research in Occupational Stress and Well-being; Emerald Group Publishing Limited: Bingley, UK, 2009; Volume 7, pp. 37-84.

47. Taylor, W.C.; Paxton, R.J.; Shegog, R.; Coan, S.P.; Dubin, A.; Page, T.F.; Rempel, D.M. Impact of booster breaks and computer prompts on physical activity and sedentary behavior among desk-based workers: A cluster-randomized controlled trial. Prev. Chronic Dis. 2016, 13, E155. [CrossRef] [PubMed]

48. Watling, C.N.; Smith, S.S.; Horswill, M.S. Stop and revive? The effectiveness of nap and active rest breaks for reducing drivers sleepiness. J. Sleep Res. 2014, 23, 261. [CrossRef] [PubMed]

49. Sun, Y.; Lim, J.; Dai, Z.; Wong, K.; Taya, F.; Chen, Y.; Li, J.; Thakor, N.; Bezerianos, A. The effects of a mid-task break on the brain connectome in healthy participants: A resting-state functional MRI study. NeuroImage 2017, 152, 19-30. [CrossRef] [PubMed] 
50. Scholz, A.; Ghadiri, A.; Singh, U.; Wendsche, J.; Peters, T.; Schneider, S. Functional work breaks in a high-demanding work environment: An experimental field study. Ergonomics 2018, 61, 255-264. [CrossRef] [PubMed]

51. Brown, D.K.; Barton, J.L.; Pretty, J.; Gladwell, V.F. Walks4Work: Assessing the role of the natural environment in a workplace physical activity intervention. Scand. J. Work Environ. Health 2014, 40, 390-399. [CrossRef]

52. Wendsche, J.; Ghadiri, A.; Bengsch, A.; Wegge, J. Antecedents and outcomes of nurses' rest break organization: A scoping review. Int. J. Nurs. Stud. 2017, 75, 65-80. [CrossRef]

53. Arrabito, G.; Ho, G.; Aghaei, B.; Burns, C.; Hou, M. Effects of vibrotactile stimulation for sustaining performance in a vigilance task. Proc. Hum. Factors Ergon. Soc. Annu. Meet. 2011, 55, 1160-1164. [CrossRef]

54. Arrabito, G.R.; Ho, G.; Aghaei, B.; Burns, C.; Hou, M. Sustained attention in auditory and visual monitoring tasks: Evaluation of the administration of a rest break or exogenous vibrotactile signals. Hum. Factors 2015, 57, 1403-1416. [CrossRef] [PubMed]

55. Balci, R.; Aghazadeh, F. A Strategy to design a work-rest schedule for VDT operators performing data entry and mental tasks. Proc. Hum. Factors Ergon. Soc. Annu. Meet. 2000, 44, 6-232. [CrossRef]

56. Balci, R.; Aghazadeh, F. The effect of work-rest schedules and type of task on the discomfort and performance of VDT users. Ergonomics 2003, 46, 455-465. [CrossRef] [PubMed]

57. Balci, R.; Aghazadeh, F. Effects of exercise breaks on performance, muscular load, and perceived discomfort in data entry and cognitive tasks. Comput. Ind. Eng. 2004, 46, 399-411. [CrossRef]

58. Beynon, C.; Reilly, T. Spinal shrinkage during a seated break and standing break during simulated nursing tasks. Appl. Ergon. 2001, 32, 617-622. [CrossRef]

59. Beynon, C.; Burke, J.; Doran, D.; Nevill, A. Effects of activity-rest schedules on physiological strain and spinal load in hospital-based porters. Ergonomics 2000, 43, 1763-1770. [CrossRef] [PubMed]

60. Boucsein, W.; Thum, M. Recovery from strain under different work/rest schedules. Proc. Hum. Factors Ergon. Soc. Annu. Meet. 1995, 39, 785-788. [CrossRef]

61. Byström, S.E.G.; Mathiassen, S.E.; Fransson-Hall, C. Physiological effects of micropauses in isometric handgrip exercise. Eur. J. Appl. Physiol. Occup. Physiol. 1991, 63, 405-411. [CrossRef]

62. Chaikumarn, M.; Nakphet, N.; Janwantanakul, P. Impact of rest-break interventions on the neck and shoulder posture of symptomatic VDU operators during prolonged computer work. Int. J. Occup. Saf. Ergon. 2018, 24, 251-259. [CrossRef]

63. Chakrabarty, S.; Sarkar, K.; Dev, S.; Das, T.; Mitra, K.; Sahu, S.; Gangopadhyay, S. Impact of rest breaks on musculoskeletal discomfort of Chikan embroiderers of West Bengal, India: A follow up field study. J. Occup. Health 2016, 58, 365-372. [CrossRef] [PubMed]

64. Chavaillaz, A.; Schwaninger, A.; Michel, S.; Sauer, J. Work design for airport security officers: Effects of rest break schedules and adaptable automation. Appl. Ergon. 2019, 79, 66-75. [CrossRef]

65. Christensen, H.; Sogaard, K.; Pilegaard, M.; Engineer, H.B.O. The importance of the work/rest pattern as a risk factor in repetitive monotonous work. Int. J. Indl. Ergon. 2000, 25, 367-373. [CrossRef]

66. Coburn, M. Influence of a 30-min break on divided attention and working memory in resident anaesthetists on daily routine. Br. J. Anaesth. 2006, 97, 315-319. [CrossRef] [PubMed]

67. Constable, S.H.; Bishop, P.A.; Nunneley, S.A.; Chen, T. Intermittent microclimate cooling during rest increases work capacity and reduces heat stress. Ergonomics 1994, 37, 277-285. [CrossRef] [PubMed]

68. Cordoza, M.; Ulrich, R.S.; Manulik, B.J.; Gardiner, S.K.; Fitzpatrick, P.S.; Hazen, T.M.; Mirka, A.; Perkins, R.S. Impact of nurses taking daily work breaks in a hospital garden on burnout. Am. J. Crit. Care 2018, 27, 508-512. [CrossRef] [PubMed]

69. Crenshaw, A.G.; Djupsjobacka, M.; Svedmark, A. Oxygenation, EMG and position sense during computer mouse work. Impact of active versus passive pauses. Eur. J. Appl. Physiol. 2006, 97, 59-67. [CrossRef]

70. Dababneh, A.J.; Swanson, N.; Shell, R.L. Impact of added rest breaks on the productivity and well being of workers. Ergonomics 2001, 44, 164-174. [CrossRef] 
71. Davis, K.G.; Kotowski, S.E. Postural variability: An effective way to reduce musculoskeletal discomfort in office work. Hum. Factors 2014, 56, 1249-1261. [CrossRef]

72. De Looze, M.P.; Bosch, T.; van Rhijn, J.W. Increasing short-term output in assembly work. Hum. Factors Ergon. Manuf. Serv. Ind. 2010, 20, 470-477. [CrossRef]

73. Dorion, D.; Darveau, S. Do micropauses prevent surgeon's fatigue and loss of accuracy associated with prolonged surgery? An experimental prospective study. Ann. Surg. 2013, 257, 256-259. [PubMed]

74. Engelmann, C.; Schneider, M.; Kirschbaum, C.; Grote, G.; Dingemann, J.; Schoof, S.; Ure, B.M. Effects of intraoperative breaks on mental and somatic operator fatigue: A randomized clinical trial. Surg. Endosc. 2011, 25, 1245-1250. [CrossRef] [PubMed]

75. Faucett, J.; Meyers, J.; Miles, J.; Janowitz, I.; Fathallah, F. Rest break interventions in stoop labor tasks. Appl. Ergon. 2007, 38, 219-226. [CrossRef] [PubMed]

76. Frey, R.; Decker, K.; Reinfried, L.; Klosch, G.; Saletu, B.; Anderer, P.; Semlitsch, H.V.; Seidler, D.; Laggner, A.N. Effect of rest on physicians' performance in an emergency department, objectified by electroencephalographic analyses and psychometric tests. Crit. Care Med. 2002, 30, 2322-2329. [CrossRef] [PubMed]

77. Galinsky, T.L.; Swanson, N.G.; Sauter, S.L.; Hurrell, J.J.; Schleifer, L.M. A field study of supplementary rest breaks for data-entry operators. Ergonomics 2000, 43, 622-638. [CrossRef]

78. Galinsky, T.L.; Swanson, N.G.; Sauter, S.L.; Dunkin, R.J.; Hurrell, J.; Schleifer, L.M. Supplementary breaks and stretching exercises for data entry operators: A follow-up field study. Am. J. Ind. Med. 2007, 50, 519-527. [CrossRef]

79. Garcia, M.-G.; Läubli, T.; Martin, B.J. Muscular and vascular issues induced by prolonged standing with different work-rest cycles with active or passive breaks. Hum. Factors 2018, 60, 806-821. [CrossRef]

80. Genaidy, A.M.; al-Rayes, S. A psychophysical approach to determine the frequency and duration of work-rest schedules for manual handling operations. Ergonomics 1993, 36, 509-518. [CrossRef]

81. Genaidy, A.M.; Delgado, E.; Bustos, T. Active microbreak effects on musculoskeletal comfort ratings in meatpacking plants. Ergonomics 1995, 38, 326-336. [CrossRef]

82. Hayashi, M.; Chikazawa, Y.; Hori, T. Short nap versus short rest: Recuperative effects during VDT work. Ergonomics 2004, 47, 1549-1560. [CrossRef]

83. Helander, M.G.; Quance, L.A. Effect of work-rest schedules on spinal shrinkage in the sedentary worker. Appl. Ergon. 1990, 21, 279-284. [CrossRef]

84. Henning, R.A.; Sauter, S.L.; Salvendy, G.; Krieg, E.F. Microbreak length, performance, and stress in a data entry task. Ergonomics 1989, 32, 855-864. [CrossRef] [PubMed]

85. Henning, R.A.; Kissel, G.V.; Maynard, D.C. A compensatory rest break system for VDT operators. Proc. Hum. Factors Ergon. Soc. Annu. Meet. 1993, 37, 905-909. [CrossRef]

86. Henning, R.A.; Ortega, A.M.; Callaghan, E.A.; Kissel, G.V. Self management of rest breaks by VDT users. Proc. Hum. Factors Ergon. Soc. Annu. Meet. 1994, 38, 754-758. [CrossRef]

87. Henning, R.A.; Kissel, G.V.; Maynard, D.C. Compensatory rest breaks for VDT operators. Int. J. Ind. Ergon. 1994, 14, 243-249. [CrossRef]

88. Henning, R.A.; Callaghan, E.A.; Guttman, J.I.; Braun, H.A. Evaluation of two self-managed rest break systems for VDT users. Proc. Hum. Factors Ergon. Soc. Annu. Meet. 1995, 39, 780-784. [CrossRef]

89. Henning, R.A.; Callaghan, E.A.; Ortega, A.M.; Kissel, G.V.; Guttman, J.I.; Braun, H.A. Continuous feedback to promote self-management of rest breaks during computer use. Int. J. Ind. Ergon. 1996, 18, 71-82. [CrossRef]

90. Henning, R.A.; Bopp, M.I.; Tucker, K.M.; Knoph, R.D.; Ahlgren, J. Team-managed rest breaks during computer-supported cooperative work. Int. J. Ind. Ergon. 1997, 20, 19-29. [CrossRef]

91. Hirose, A.; Nagasaka, A. The effects of the level of alertness during the rest period on subsequent performance. Int. J. Occup. Saf. Ergon. 2003, 9, 479-490. [CrossRef]

92. Hofer-Tinguely, G.; Achermann, P.; Landolt, H.-P.; Regel, S.J.; Retey, J.V.; Durr, R.; Borbely, A.A.; Gottselig, J.M. Sleep inertia: Performance changes after sleep, rest and active waking. Brain Res. Cogn. Brain Res. 2005, 22, 323-331. [CrossRef]

93. Howard, M.E.; Radford, L.; Jackson, M.L.; Swann, P.; Kennedy, G.A. The effects of a 30-minute napping opportunity during an actual night shift on performance and sleepiness in shift workers. Biol. Rhythm Res. 2010, 41, 137-148. [CrossRef] 
94. Irmak, A.; Bumin, G.; Irmak, R. The effects of exercise reminder software program on office workers' perceived pain level, work performance and quality of life. Work 2012, 41, 5692-5695. [PubMed]

95. Januario, L.B.; Madeleine, P.; Cid, M.M.; Samani, A.; Oliveira, A.B. Can exposure variation be promoted in the shoulder girdle muscles by modifying work pace and inserting pauses during simulated assembly work? Appl. Ergon. 2018, 66, 151-160. [CrossRef] [PubMed]

96. Kakarot, N.; Mueller, F.; Bassarak, C. Activity-rest schedules in physically demanding work and the variation of responses with age. Ergonomics 2012, 55, 282-294. [CrossRef] [PubMed]

97. Karwowski, W.; Eberts, R.; Salvendy, G.; Noland, S. The effects of computer interface design on human postural dynamics. Ergonomics 1994, 37, 703-724. [CrossRef] [PubMed]

98. Kennedy, G.A.; Ball, H. Power break: A brief hypnorelaxation program to reduce work-related fatigue and improve work satisfaction, productivity, and well-being. Aust. J. Clin. Exp. Hypn. 2007, 35, 169-193.

99. Kietrys, D.M.; Galper, J.S.; Verno, V. Effects of at-work exercises on computer operators. Work 2007, 28, 67-75.

100. Kopardekar, P.; Mital, A. The effect of different work-rest schedules on fatigue and performance of a simulated directory assistance operator's task. Ergonomics 1994, 37, 1697-1707. [CrossRef]

101. Krajewski, J.; Sauerland, M.; Wieland, R. Relaxation-induced cortisol changes within lunch breaks-An experimental longitudinal worksite field study. J. Occup. Organ. Psychol. 2011, 84, 382-394. [CrossRef]

102. Lacaze, D.H.D.C.; Sacco, I.D.C.N.; Rocha, L.E.; Pereira, C.A.D.B.; Casarotto, R.A. Stretching and joint mobilization exercises reduce call-center operators' musculoskeletal discomfort and fatigue. Clinics 2010, 65, 657-662. [CrossRef]

103. Larsen, M.K.; Samani, A.; Madeleine, P.; Olsen, H.B.; Søgaard, K.; Holtermann, A. Short-term effects of implemented high intensity shoulder elevation during computer work. BMC Musculoskelet. Disord. 2009, 10. [CrossRef] [PubMed]

104. Lim, J.; Kwok, K. The Effects of varying break length on attention and time on task. Hum. Factors 2016, 58, 472-481. [CrossRef] [PubMed]

105. Lim, J.; Quevenco, F.-C.; Kwok, K. EEG alpha activity is associated with individual differences in post-break improvement. NeuroImage 2013, 76, 81-89. [CrossRef] [PubMed]

106. Lim, J.; Teng, J.; Wong, K.F.; Chee, M.W.L. Modulating rest-break length induces differential recruitment of automatic and controlled attentional processes upon task reengagement. Neuroimage 2016, 134, 64-73. [CrossRef] [PubMed]

107. Mailey, E.L.; Rosenkranz, S.K.; Casey, K.; Swank, A. Comparing the effects of two different break strategies on occupational sedentary behavior in a real world setting: A randomized trial. Prev. Med. Rep. 2016, 4, 423-428. [CrossRef] [PubMed]

108. Mathiassen, S.E.; Winkel, J. Physiological comparison of three interventions in light assembly work: Reduced work pace, increased break allowance and shortened working days. Int. Arch. Occup. Environ. Health 1996, 68, 94-108. [CrossRef] [PubMed]

109. Mathiassen, S.E.; Hallman, D.M.; Lyskov, E.; Hygge, S. Can cognitive activities during breaks in repetitive manual work accelerate recovery from fatigue? A controlled experiment. PLoS ONE 2014, 9, e112090. [CrossRef]

110. McLean, L.; Tingley, M.; Scott, R.N.; Rickards, J. Computer terminal work and the benefit of microbreaks. Appl. Ergon. 2001, 32, 225-237. [CrossRef]

111. Miller, B.J.; Fathallah, F.A. The effects of a stooped work task on the muscle activity and kinematics of the lower back. Proc. Hum. Factors Ergon. Soc. Ann. Meet. 2006, 50, 1284-1288. [CrossRef]

112. Mitra, B.; Cameron, P.A.; Mele, G.; Archer, P. Rest during shift work in the emergency department. Aust. Health Rev. 2008, 32, 246-251. [CrossRef]

113. Mohamed, M.A.; Radwan, N.L. Optimal work-rest schedules for computer users. Int. J. Physiother. 2017, 4, 71-76. [CrossRef]

114. Nakphet, N.; Chaikumarn, M.; Janwantanakul, P. Effect of different types of rest-break interventions on neck and shoulder muscle activity, perceived discomfort and productivity in symptomatic VDU operators: A randomized controlled trial. Int. J. Occup. Saf. Ergon. 2014, 20, 339-353. [CrossRef] [PubMed]

115. Neri, D.F.; Oyung, R.L.; Colletti, L.M.; Mallis, M.M.; Tam, P.Y.; Dinges, D.F. Controlled breaks as a fatigue countermeasure on the flight deck. Aviat. Space Environ. Med. 2002, 73, 654-664. 
116. O’Donnell, E.; Landolt, K.; Hazi, A.; Dragano, N.; Wright, B.J. An experimental study of the job demand-control model with measures of heart rate variability and salivary alpha-amylase: Evidence of increased stress responses to increased break autonomy. Psychoneuroendocrinology 2015, 51, 24-34. [CrossRef] [PubMed]

117. Oriyama, S.; Miyakoshi, Y.; Kobayashi, T. Effects of Two 15-min naps on the subjective sleepiness, fatigue and heart rate variability of night shift nurses. Ind. Health 2014, 52, 25-35. [CrossRef] [PubMed]

118. Rahman, I.A.; Mohamad, N.; Rohani, J.M.; Zein, R.M. The impact of work rest scheduling for prolonged standing activity. Ind. Health 2018, 56, 492-499. [CrossRef] [PubMed]

119. Reyner, L.A.; Horne, J.A. Suppression of sleepiness in drivers: Combination of caffeine with a short nap. Psychophysiology 1997, 34, 721-725. [CrossRef]

120. Ross, H.; Russell, P.; Helton, W. Effects of breaks and goal switches on the vigilance decrement. Exp. Brain Res. 2014, 232, 1729-1737. [CrossRef]

121. Rupp, M.A.; Sweetman, R.; Sosa, A.E.; Smither, J.A.; McConnell, D.S. Searching for affective and cognitive restoration: Examining the restorative effects of casual video game play. Hum. Factors 2017, 59, 1096-1107. [CrossRef]

122. Samani, A.; Holtermann, A.; Sogaard, K.; Madeleine, P. Effects of eccentric exercise on trapezius electromyography during computer work with active and passive pauses. Clin. Biomech. 2009, 24, 619-625. [CrossRef]

123. Samani, A.; Holtermann, A.; Sogaard, K.; Madeleine, P. Active pauses induce more variable electromyographic pattern of the trapezius muscle activity during computer work. J. Electromyogr. Kinesiol. 2009, 19, e430-e437. [CrossRef] [PubMed]

124. Schnieder, S.; Stappert, S.; Takahashi, M.; Fricchione, G.L.; Esch, T.; Krajewski, J. Sustainable reduction of sleepiness through salutogenic self-care procedure in lunch breaks: A pilot study. Evid. Based Complement. Altern. Med. 2013, 2013, 387356. [CrossRef] [PubMed]

125. Sheahan, P.J.; Diesbourg, T.L.; Fischer, S.L. The effect of rest break schedule on acute low back pain development in pain and non-pain developers during seated work. Appl. Ergon. 2016, 53, 64-70. [CrossRef] [PubMed]

126. Sommer, W.; Stürmer, B.; Shmuilovich, O.; Martin-Loeches, M.; Schacht, A. How about lunch? Consequences of the meal context on cognition and emotion. PLoS ONE 2013, 8, e70314. [CrossRef] [PubMed]

127. Steinborn, M.B.; Huestegge, L. A walk down the lane gives wings to your brain. Restorative benefits of rest breaks on cognition and self-control. Appl. Cogn. Psychol. 2016, 30, 795-805. [CrossRef]

128. St-Onge, N.; Samani, A.; Madeleine, P. Integration of active pauses and pattern of muscular activity during computer work. Ergonomics 2017, 60, 1228-1239. [CrossRef]

129. Sundelin, G. Patterns of electromyographic shoulder muscle fatigue during MTM-paced repetitive arm work with and without pauses. Int. Arch. Occup. Environ. Health 1993, 64, 485-493. [CrossRef]

130. Sundelin, G.; Hagberg, M. The effects of different pause types on neck and shoulder EMG activity during VDU work. Ergonomics 1989, 32, 527-537. [CrossRef]

131. Takahashi, M.; Fukuda, H.; Arito, H. Brief naps during post-lunch rest: Effects on alertness, performance, and autonomic balance. Eur. J. Appl. Physiol. Occup. Physiol. 1998, 78, 93-98. [CrossRef]

132. Takahashi, M.; Nakata, A.; Haratani, T.; Ogawa, Y.; Arito, H. Post-lunch nap as a worksite intervention to promote alertness on the job. Ergonomics 2004, 47, 1003-1013. [CrossRef]

133. Taylor, W.C.; King, K.E.; Shegog, R.; Paxton, R.J.; Evans-Hudnall, G.L.; Rempel, D.M.; Chen, V.; Yancey, A.K. Booster Breaks in the workplace: Participants' perspectives on health-promoting work breaks. Health Educ. Res. 2013, 28, 414-425. [CrossRef] [PubMed]

134. Tiwari, P.S.; Gite, L.P. Evaluation of work-rest schedules during operation of a rotary power tiller. Int. J. Ind. Ergon. 2006, 36, 203-210. [CrossRef]

135. Torrente, P.; Kinnunen, U.; Sianoja, M.; de Bloom, J.; Korpela, K.; Tuomisto, M.T.; Lindfors, P. The effects of relaxation exercises and park walks during workplace lunch breaks on physiological recovery. Scan. J. Work Organ. Psychol. 2017, 2, 1-15. [CrossRef]

136. Van den Heuvel, S.G.; de Looze, M.P.; Hildebrandt, V.H.; Thé, K.H. Effects of software programs stimulating regular breaks and exercises on work-related neck and upper-limb disorders. Scand. J. Work Environ. Health 2003, 29, 106-116. [CrossRef] [PubMed] 
137. Van Dieen, J.H.; Oude Vrielink, H.H. Evaluation of work-rest schedules with respect to the effects of postural workload in standing work. Ergonomics 1998, 41, 1832-1844. [CrossRef] [PubMed]

138. Wang, L.; Pei, Y. The impact of continuous driving time and rest time on commercial drivers' driving performance and recovery. J. Saf. Res. 2014, 50, 11-15. [CrossRef] [PubMed]

139. Wollseiffen, P.; Ghadiri, A.; Scholz, A.; Strüder, H.K.; Herpers, R.; Peters, T.; Schneider, S. Short bouts of intensive exercise during the workday have a positive effect on neuro-cognitive performance: Neuroexercise. Stress Health 2015, 32, 514-523. [CrossRef] [PubMed]

(C) 2019 by the authors. Licensee MDPI, Basel, Switzerland. This article is an open access article distributed under the terms and conditions of the Creative Commons Attribution (CC BY) license (http://creativecommons.org/licenses/by/4.0/). 